\title{
Removal of Safranin Dye from Wastewater Using Khulays Natural Bentonite
}

\author{
S. S. Al-Shahrani \\ Chemical and Material Engineering Department, King Abdulaziz University, Jeddah 21589, Saudi \\ Arabia
}

ssaalshahrani@kau.edu.sa

\begin{abstract}
Khulays natural bentonite as low-cost adsorbent was investigated to be used to remove safranin dye from wastewater. The removal process was studied using batch adsorption experiments. The effect of different parameters on the adsorption process was investigated including contact time, initial safranin dye concentration, initial solution $\mathrm{pH}$ and Khulays natural bentonite dosage. Adsorption isotherms were applied to estimate the equilibrium characteristics of the adsorption process, evaluate the applicability of the process and suggest the appropriate design for the adsorption system. Adsorption kinetics were investigated using pseudo-first-order model and pseudo-second-order model to fit the experimental data. The results revealed that the adsorption process achieved equilibrium after 80 minutes. The removal process is initial solution $\mathrm{pH}$ dependent where the removal percentage of safranin dye gradually increased as the initial safranin dye solution $\mathrm{pH}$ increased. They also showed that as the initial safranin dye concentration increased the removal percentage decreased because of limited active sites on bentonite surfaces which consequently saturated with safranin dye. The experimental data was well fitted with Langmuir model more than with Freundlich model and the maximum adsorption capacity was equal to $294.1 \mathrm{mg} / \mathrm{g}$. Moreover, the experimental results showed that the adsorption of safranin dye onto Khulays natural bentonite followed pseudo second-order model.

Keywords: Khulays natural bentonite, Safranin dye adsorption, Safranin O adsorption, Adsorption isotherms, Kinetics.
\end{abstract}

\section{Introduction}

Dyes are common compounds used in different industries such as textile, printing, paper, plastic, food, cosmetic, ... etc. ${ }^{[1-5]}$. The discharged streams from these industries as a wastewater may cause a serious pollutant problem ${ }^{[6]}$. Furthermore, they may enter the food chain if they are discharged into water supplies and ground water. They may be considered as a major threat to the human health and marine lives. Some of these dyes may degrade to produce toxic and carcinogens compounds. Safranin dye (Basic red 2 (BR2)), known as safranin $\mathrm{O}$, is one of these dyes that has been widely used in textile, leather and food industries ${ }^{[7]}$.

High exposure of safranin dye causes skin irritation when contacted with skin, causes irritation when contacted with eye and causes respiratory tract irritation when inhaled ${ }^{[8]}$. Furthermore, it is known as a carcinogenic dye, which may affect marine life when present in wastewater ${ }^{[9]}$.

Many research studies have been conducted to remove dyes from wastewater using several techniques, such as adsorption, membrane filtration, coagulation, 
photodegradation, ozonation, and biological degradation $^{[10-15]}$. Adsorption process is considered as the most efficient process due to its low cost, easy design and operation. Activated carbon is considered as a common adsorbent used to remove dyes from aqueous solutions. Alternatively, due to its high cost, numerous studies were conducted to find alternative adsorbent to make the adsorption process more economical. Different adsorbents were investigated for adsorption of dyes from wastewater such as silica ${ }^{[16]}$, zeolite ${ }^{[17]}$, peat ${ }^{[18]}$, kaolinite ${ }^{[19]}$ and bentonite ${ }^{[20-23]}$. The objective of this research is to study the feasibility of applying Khulays natural bentonite to remove safranin dye from wastewater.

\section{Materials and Methods}

\subsection{Chemicals}

Safranin dye (basic red 2) is a cationic dye that was purchased from Loba Chemie (C. I. : 50240; MW: $350.84 \mathrm{C}_{20} \mathrm{H}_{19} \mathrm{ClN}_{4}$; Grade: for microscopy) and used as received. The chemical structure of safranin dye is shown in Fig. 1(a). Chemicals used to control solution $\mathrm{pH}$ such as Hydrochloric acid $(\mathrm{HCl})$ and Sodium hydroxide $(\mathrm{NaOH})$ were purchased from Sigma-Aldrich. All chemicals used in this research were of analytical reagent grade and double-distilled water was used to prepare various solutions.

\subsection{Adsorbent}

The adsorbent material used in this study is Khulays natural bentonite. It was obtained from Khulays area, $95 \mathrm{~km}$ north of Jeddah, western province of Saudi Arabia. The samples were collected as ungrounded rocks. Accordingly, they were dried in the oven for 24 hours at $105{ }^{\circ} \mathrm{C}$. The dried samples underwent crushing and sieving processes to reduce their size to -200 mesh $(74 \mu \mathrm{m})$. The measured surface area $\left(\mathrm{N}_{2}\right.$-BET method) of Khulays natural bentonite was $64 \mathrm{~m}^{2} / \mathrm{g}$ and the chemical composition is shown in Table 1. The scanning electron microscopy (SEM) image of the natural Khulays natural bentonite is shown in Fig. 1(b). The image shows a mixture of spherical as well as semi-flower structure molecules with high pores on the bentonite surface, which gives a good indication for Khulays bentonite to be a good adsorbent.

\subsection{Adsorption Process}

The adsorption of safranin dye onto Khulays natural bentonite was conducted using batch technique. $1000 \mathrm{mg} / \mathrm{l}$ stock solution of safranin dye was prepared by diluting appropriate amount of safranin dye in double-distilled water. Different initial safranin dye concentrations were prepared by diluting the stock solution as required. A known amount of Khulays natural bentonite was added to each $100 \mathrm{ml}$ conical flask filled with $50 \mathrm{ml}$ of dye solution at a required concentration. Afterward, the conical flasks were placed in a horizontal shaker with water bath (model. JULABO SW 22) working at 200 rpm and $25^{\circ} \mathrm{C}$. At certain contact time, flasks were taken out from the shaker, and safranin dye solution was separated from bentonite using centrifugation (model: ROTOFIX 32A) at $4000 \mathrm{rpm}$ for $15 \mathrm{~min}$. Subsequently, the supernatant solutions were analyzed for safranin dye concentration using UV-visible spectrophotometer (model: APEL PD-303UV) at a wavelength of maximum absorbance 519 $\mathrm{nm}$. The removal percentage of safranin dye was evaluated using the following equation:

Safranin dye removal $(\%)=\frac{\mathrm{C}_{\mathrm{i}-} \mathrm{C}_{\mathrm{f}}}{\mathrm{C}_{\mathrm{i}}} \times 100$

where $C_{i}$ and $C_{f}$ are the initial and final concentration of safranin dye respectively in $\mathrm{mg} / \mathrm{l}$.

\section{Results and Discussion}

Removal of safranin dye from wastewater by adsorption onto Khulays natural 
bentonite was investigated. Different experiments were conducted to study different factors that may affect the adsorption process as follows.

\subsection{Contact Time}

The effect of mixing time on the adsorption process was investigated to determine the maximum adsorption of safranin dye using different concentration of dye solution (100-400 mg/l) as a function of mixing time. For each run, $50 \mathrm{ml}$ of safranin dye solution at a certain dye concentration was continuously stirred with $0.025 \mathrm{~g}$ of Khulays natural bentonite at $200 \mathrm{rpm}$ during different time intervals $(5-180 \mathrm{~min})$ at $25{ }^{\circ} \mathrm{C}$. The solution $\mathrm{pH}$ for all experiments was kept unchanged at 5.8. After each run, the mixture was separated using centrifugation and the supernatant was measured for safranin dye concentration. Figure 2 shows the percentage of dye removal versus time. The removal percentage increased sharply at the beginning of each experiment as a result of a large adsorption active site on Khulays natural bentonite. Moreover, the adsorption rate of safranin dye on Khulays natural bentonite was fast where shaking the mixture for 80 min was sufficient for the process to reach equilibrium and its maximum adsorption capacity. The short equilibrium time is an important factor for reducing the cost of the adsorption process when used in industry. As shown from Fig. 2, the initial concentration is an important factor, where the adsorption rate will decrease as the concentration of safranin dye increases, which hinders the removal efficiency of Khulays natural bentonite.

\subsection{Initial Solution $\mathrm{pH}$}

The removal of safranin dye from wastewater was studied over a range of $\mathrm{pH}$ from 3 to $10.0 .025 \mathrm{gm}$ of bentonite was added to $50 \mathrm{ml}$ of safranin dye solution at $300 \mathrm{mg} / \mathrm{l}$ dye concentration. The mixture was continuously shaken for 80 min (equilibrium time) at $200 \mathrm{rpm}$ and $25{ }^{\circ} \mathrm{C}$. Afterward, the mixture was separated and the supernatant was measured for safranin dye concentration. As shown in Fig. 3, the removal percentage of safranin dye was gradually increased with initial solution $\mathrm{pH}$ increase. This attributed to the decrease of $\mathrm{H}^{+}$ions in the dye solution with increasing of the solution $\mathrm{pH}$, where hydrogen ions compete with the cation groups of the safranin dye. Moreover, the decrease in the removal percentage may be attributed to the decrease of electrostatic attraction that occurs between bentonite sites and safranin dye ${ }^{[24-27]}$.

\subsection{Effect of Initial Safranin Dye Concentration}

Removal of safranin dye from solution was studied using different safranin dye concentration ranging from 100 to $600 \mathrm{mg} / \mathrm{l}$. 0.025 gram of Khulays natural bentonite was added to each flask containing specified safranin dye concentration and mixed for 80 min at $200 \mathrm{rpm}$ and $25^{\circ} \mathrm{C}$. Figure 4(a) shows that removal percentage of safranin dye decreased as the initial concentration of safranin dye increased. This is due to the limited active site on bentonite, which decreases with increasing dye solution until bentonite active sites are saturated with safranin dye. After saturation, no further safranin dye is removed from the solution, which leads to hinder the removal efficiency [24].

\subsection{Effect of Bentonite Dosage}

Increasing the adsorptive site on bentonite is an important factor affecting the removal process. Effect of bentonite amount on the removal percentage of safranin dye was investigated over a range of bentonite dosage from 0.0125 to $0.15 \mathrm{gm}$. The specified bentonite dosage was added to conical flask containing $50 \mathrm{ml}$ of $300 \mathrm{mg} / \mathrm{l}$ safranin dye solution and mixed for $80 \mathrm{~min}$ to ensure the 
equilibrium was achieved. The shaker was operated at $200 \mathrm{pm}$ and $25{ }^{\circ} \mathrm{C}$. Figure 4(b) shows fast increase of dye removal with the increase of Khulays natural bentonite dosage. This is due to the increase of adsorption sites with increasing the amount of bentonite. Further increase of the amount of bentonite removed all of the dye in the solution, which means all of safranin dye has been adsorbed on bentonite active surfaces. At low dye concentration, there is a sufficient number of active sites available to adsorb the dye from the solution. Increasing the concentration of safranin dye in the solution will saturate the adsorption sites in the bentonite and reduce the removal efficiency.<smiles>Cc1cc2nc3cc(C)c(N)cc3[n+](-c3ccccc3)c2cc1N</smiles>

(a)

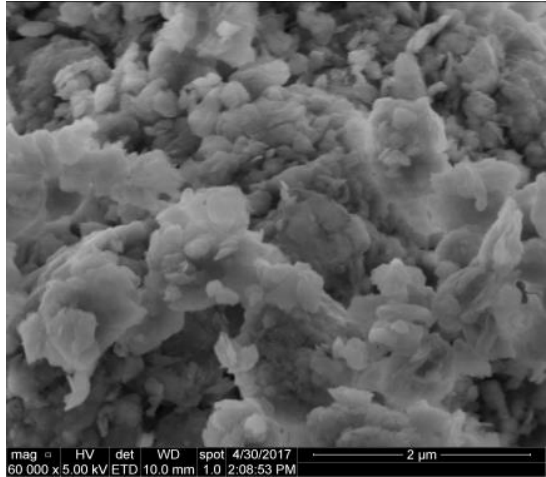

(b)

Fig. 1. (a) Chemical structure of safranin dye; (b) SEM image of Khulays natural bentonite.

Table 1. Chemical composition of Khulays natural bentonite $(\%)^{[23]}$.

\begin{tabular}{llllllllllll}
\hline $\mathrm{SiO}_{2}$ & $\mathrm{Al}_{2} \mathrm{O}_{3}$ & $\mathrm{Fe}_{2} \mathrm{O}_{2}$ & $\mathrm{TiO}_{2}$ & $\mathrm{MgO}$ & $\mathrm{CaO}$ & $\mathrm{K}_{2} \mathrm{O}$ & $\mathrm{Na}_{2} \mathrm{O}$ & $\mathrm{MnO}$ & $\mathrm{SO}_{3}$ & $\mathrm{P}_{2} \mathrm{O}_{5}$ & L.O.I. $\left(1000^{\circ} \mathrm{C}\right)$ \\
\hline 52.88 & 17.59 & 10.15 & 1.1 & 2.3 & 1.26 & 0.64 & 1.26 & 0.15 & $<0.05$ & 0.27 & 11.49 \\
\hline
\end{tabular}

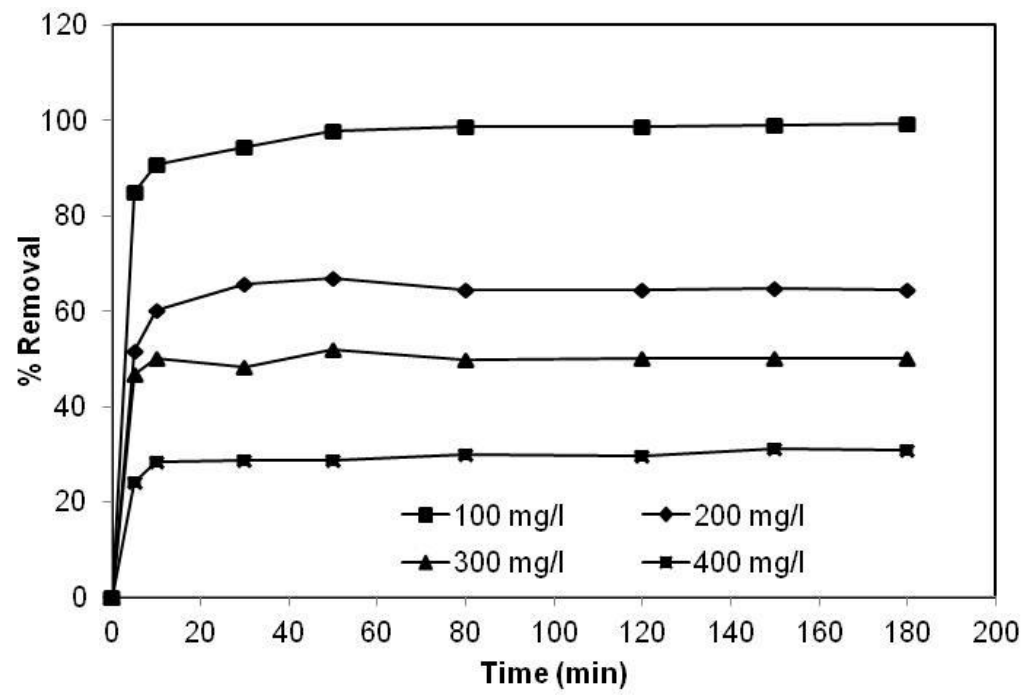

Fig. 2. Effect of contact time on the removal of safranin dye. 


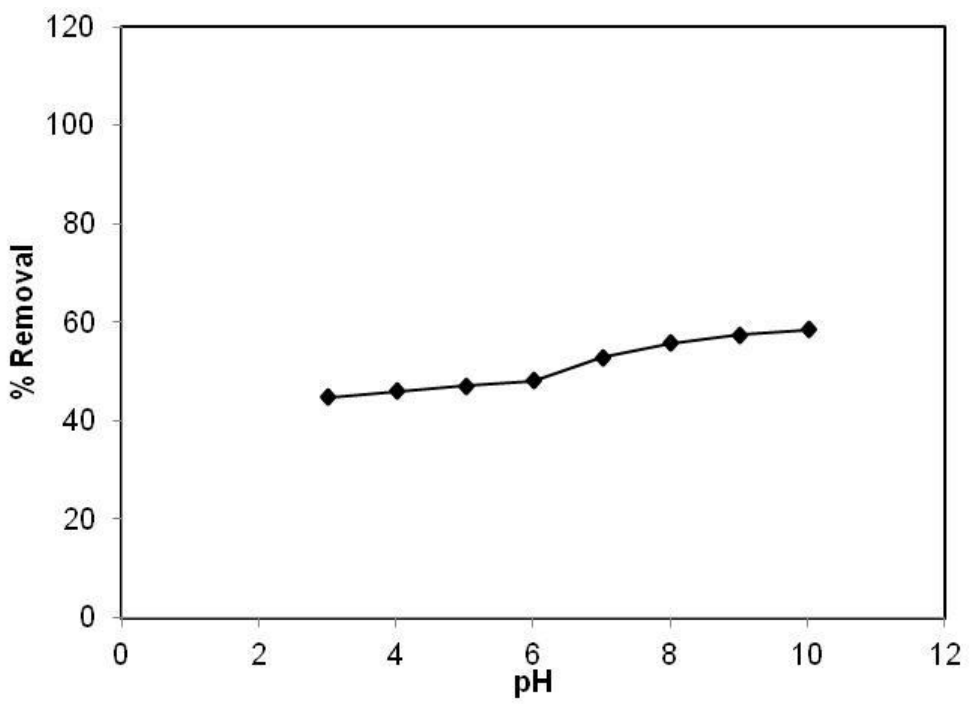

Fig. 3. Effect of initial solution pH on the removal of safranin dye.

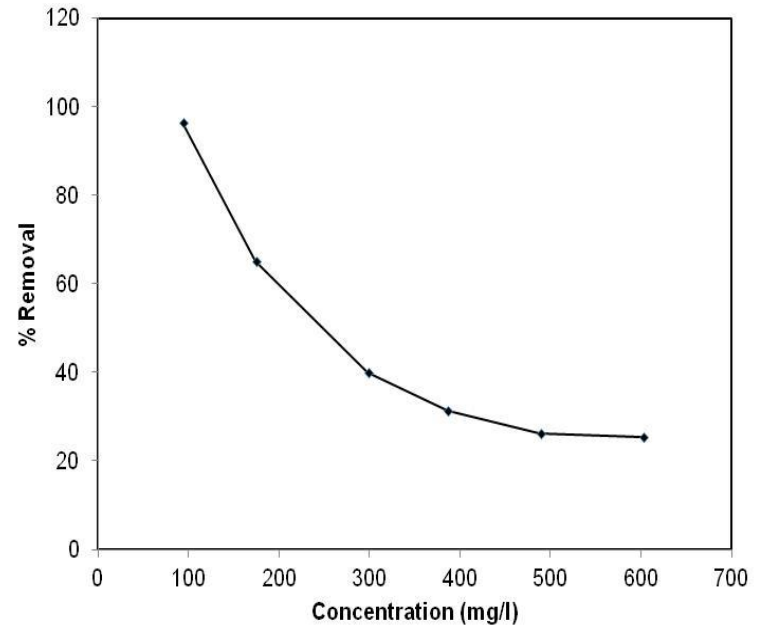

(a)

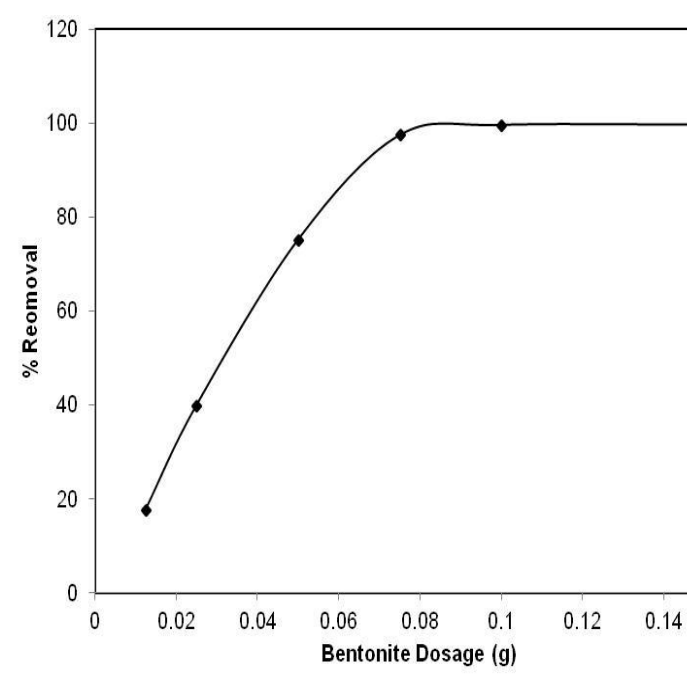

(b)

Fig. 4. (a) Effect of initial safranin dye concentration on the removal percentage wastewater; (b) Effect of bentonite amount on the removal of safranin dye from wastewater.

\subsection{Adsorption Isotherms}

Adsorption isotherm can help to understand the mechanism of the process and how dye molecules distribute themselves between liquid and solid phases at equilibrium. Moreover, it is considered the most important parameter for designing a desired adsorption system. The adsorptive capacity of Khulays natural bentonite can be explained by adsorption isotherms. In this project, Langmuir and Freundlich models as the most commonly used mathematical models were evaluated to describe the adsorption of safranin dye onto Khulays natural bentonite. Langmuir model assumes that adsorption occurs on a monolayer of the homogeneous surface. It is represented by the following equation ${ }^{[28]}$ :

$$
\frac{\mathrm{C}_{\mathrm{eq}}}{\mathrm{q}_{\mathrm{eq}}}=\frac{\mathrm{C}_{\mathrm{eq}}}{\mathrm{Q}_{\max }}+\frac{1}{\mathrm{Q}_{\max } \mathrm{K}_{\mathrm{L}}}
$$


where $\mathrm{Ceq}$ is the dye concentration at equilibrium in the solution $(\mathrm{mg} / \mathrm{l}), \mathrm{q}_{\mathrm{eq}}$ is the amount of dye removed per gram of bentonite, $\mathrm{K}_{\mathrm{L}}$ is the Langmuir constant $(1 / \mathrm{mg})$, and $\mathrm{Q}_{\max }$ is the maximum sorption capacity $(\mathrm{mg} / \mathrm{g})$.

Freundlich model assumes that adsorption occurs on heterogeneous surfaces and is represented by the following equation [29].

$$
\log q_{\text {eq }}=\frac{1}{n} \log C_{e q}+\log K_{F}
$$

where $\mathrm{K}_{\mathrm{F}}$ and $\mathrm{n}$ are Freundlich constants, stand for the adsorption intensity and the sorption capacity respectively. Figures 5(a) and 5(b) show the fit of the experimental data with both Langmuir and Freundlich models respectively. They show the data were well fitted more with Langmuir model than with Freundlich model. As reported before ${ }^{[30-32]}$, safranin dissolves in water and is considered as cationic dye, which can be electrostatically adsorbed onto negative charge sites on bentonite forming Langmuir monolayer. Langmuir and Freunlich constants are listed in Table 2. The maximum adsorption capacity of safranin dye on Khulays natural bentonite is equal to $294.1 \mathrm{mg} / \mathrm{g}$, which indicates high adsorption capacity compared to other adsorbents [24,33-34]. As the value of Freundlich constant $1 / \mathrm{n}$ less than 1 , it means adsorption process is favorable ${ }^{[35]}$.

Table 2. Langmuir and Freundlich constants.

\begin{tabular}{|c|c|c|}
\hline \multicolumn{2}{|c|}{ Isotherm parameters } & values \\
\hline \multicolumn{2}{|c|}{ Qmax (mg/g) } & 294.1 \\
\hline Langmuir & $\mathrm{K}_{\mathrm{L}} \quad(\mathrm{L} / \mathrm{mg})$ & 0.042 \\
\hline \multicolumn{2}{|c|}{$\mathrm{R}^{2}$} & 0.973 \\
\hline \multicolumn{2}{|c|}{$\mathrm{K}_{\mathrm{F}} \quad(\mathrm{mg} / \mathrm{g})$} & 159.3 \\
\hline \multirow{2}{*}{\multicolumn{2}{|c|}{ Freundlich $\quad 1 / \mathrm{n}$}} & 0.086 \\
\hline & & 0.85 \\
\hline
\end{tabular}

\subsection{Adsorption Kinetics}

The adsorption kinetics models, pseudofirst order and pseudo-second order were tested to investigate the removal process. These two models were used to fit the experimental data in order to find the mechanism of the adsorption process and the step controlling the adsorption process. The pseudo-first order model is represented by the following equation ${ }^{[36]}$ :

$$
\log \left(q_{\text {eq }}-q_{t}\right)=\log q_{\text {eq }}-\frac{K_{1}}{2.303} t
$$

where $\mathrm{q}_{\mathrm{t}}$ is the amount of safranin dye adsorbed at any time $t(\mathrm{mg} / \mathrm{g})$ and $\mathrm{K}_{1}$ is the adsorption process constant $\left(\min ^{-1} 1\right)$.

Pseudo second-order model is represented by the following equation ${ }^{[37]}$ :

$$
\frac{t}{q_{t}}=\frac{1}{K_{2} q_{e q}^{2}}+\frac{1}{q_{e q}} t
$$

where $K_{2}$ is the rate constant for the adsorption process ( $\mathrm{g} / \mathrm{gm} \mathrm{min})$.

Adsorption kinetics was investigated experimentally by studying the influence of mixing time on the sorption rate at a different time intervals (5-180 $\mathrm{min})$. The adsorption process was conducted using two dye initial concentrations $(200 ; 300 \mathrm{mg} / \mathrm{l})$. For each run, $50 \mathrm{ml}$ of certain dye concentrations were continuously stirred with $0.025 \mathrm{~g}$ of Khulays natural bentonite at $200 \mathrm{rpm}$ and $25{ }^{\circ} \mathrm{C}$. Afterward, the mixture of dye solution and bentonite was separated and the supernatant was measured for safranin dye concentration. The experimental data obtained from this study were fitted with both pseudo-first order and pseudo-second order models as illustrated in Fig. 6(a) and Fig. 6(b) respectively. The trends of the experimental data prove that the adsorption process follow pseudo-second order. The determination coefficient $\left(\mathrm{R}^{2}\right)$ values for pseudo-second order sorption model (0.999) are higher than the determination coefficient $\left(\mathrm{R}^{2}\right)$ values for pseudo-first order kinetic $(<0.5)$. This means the experimental data is clearly better explained by pseudo second-order kinetic model. As reported 
before, the process follows chemisorption kinetic ${ }^{[37]}$.

\section{Conclusion}

Khulays natural bentonite, which was prepared and used in this study, showed promising results for removing of safranin dye from wastewater. Khulays natural bentonite was studied as a function of various parameters affecting the removal process. The results revealed that increasing contact time increases safranin dye removal percentage, and the adsorption equilibrium was achieved after mixing the dye solution with bentonite for $80 \mathrm{~min}$. The adsorption process is $\mathrm{pH}$ dependent. Increasing of safranin dye in the solution decreased the removal percentage

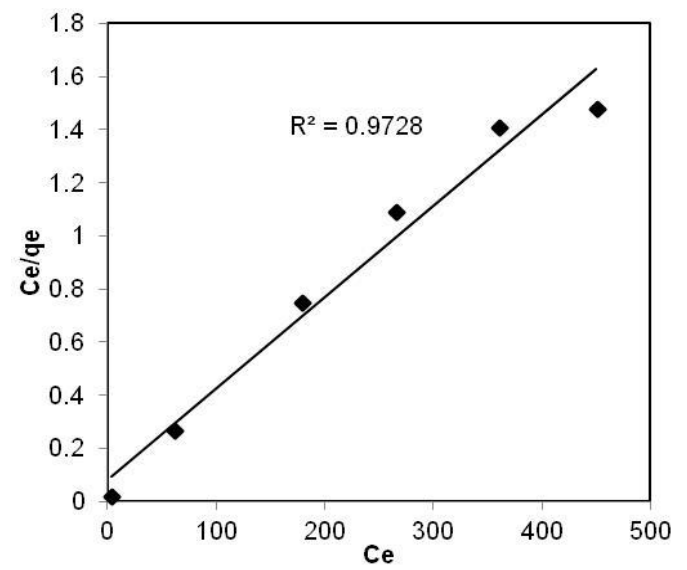

(a) while increasing bentonite dosage increased the removal percentage as a result of active sites increase on bentonite surface. The dye sorption isotherm fits the Langmuir model more than the Freunlich model. The kinetic study was best described by pseudo-second order with correlation coefficient $\left(\mathrm{R}^{2}\right)$ close to unity. The maximum adsorption capacity of Khulays natural bentonite equals to 294.1 $\mathrm{mg} / \mathrm{g}$. The results of this project prove that the Khulays natural bentonite is a promising adsorbent for safranin dye from wastewater. Future experimental work can be conducted to investigate the capability of Khulays natural bentonite for the treatment of wastewater contaminated with other basic dyes.

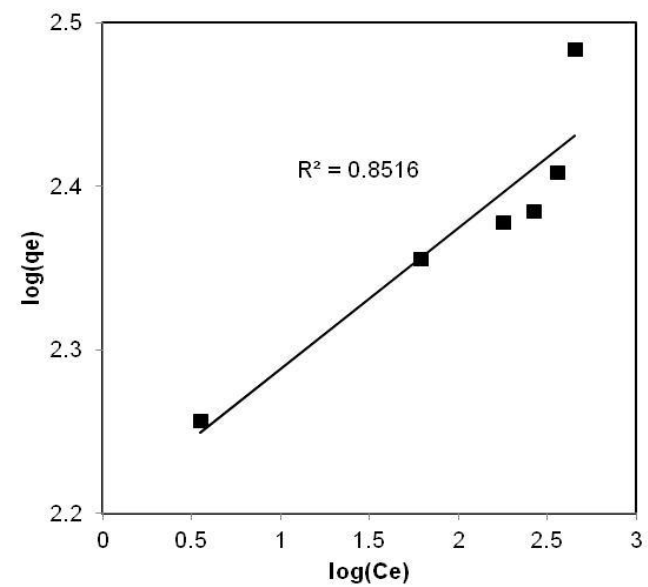

(b)

Fig. 5. Experimental data fitted to linearize: (a) Langmuir model; (b) Freundlich model.

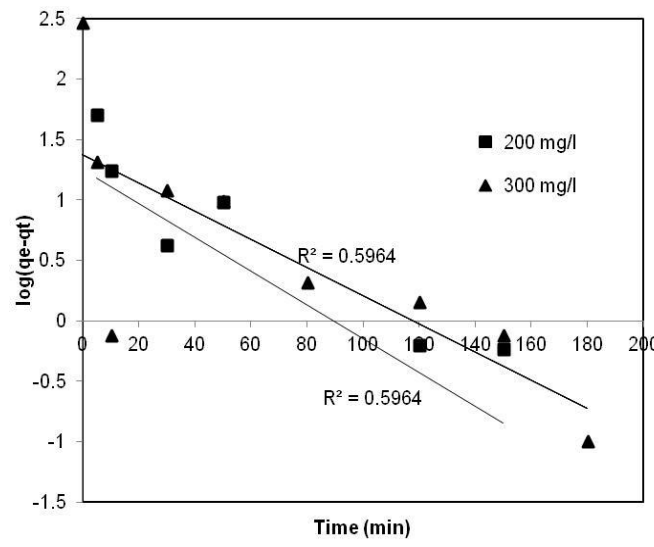

(a)

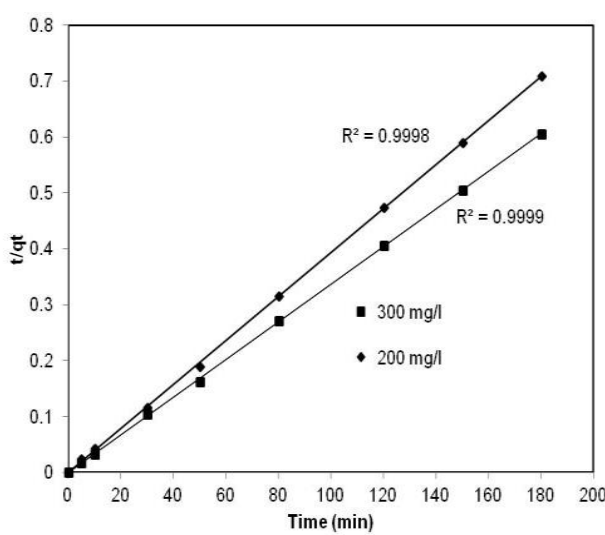

(b)

Fig. 6. Adsorption kinetics plots: (a) Pseudo first-order model; (b) Pseudo second-order model. 


\section{References}

[ 1] Gupta, G.S.; Shukla, S.P.; Prasad, G. and Singh, VN. (1992). China clay as an adsorbent for dye house wastewaters. Environ. Technol.,139: 25-36. doi: https://doi.org/10.1080/09593339209385228

[ 2] Sokolowska-Gajda, J.; Freeman, H.S. and Reife, A. (1996). Synthetic dyes based on environmental considerations: 2. Iron complexed formazan dyes. Dyes Pigm., 30: 1-20. doi: https://doi.org/10.1016/01437208(95)00048-8

[ 3] Kabadasil, I.; Tunay, O. and Orhon, D. (1999). Wastewater control and management in a leathertanning district. Water Sci Technol., 40(1): 261-267. doi: https://doi.org/10.1016/S0273-1223(99)00393-5

[ 4] Hu, Y.; Guo, T.; Ye, X.; Li, Q.; Guo, M.; Liu, H. and Wu, Z. (2013). Dye adsorption by resins: Effect of ionic strength on hydrophobic and electrostatic interactions. Chem. Eng. J., 228: 392-397. doi: https://doi.org/10.1016/j.cej.2013.04.116

[ 5] Mehrorang Ghaedi; Saeid Khodadoust; Hossein Sadeghi; Mohammad Ali Khodadoust; Raham Armand and Allahdad Fatehi (2015). Application of ultrasonic radiation for simultaneous removal of auramine $\mathrm{O}$ and safranine $\mathrm{O}$ by copper sulfide nanoparticles: Experimental design. Spectrochim. Acta Part A, 136: 1069-1075. doi: https://doi.org/10.1016/j.saa.2014.09.131

[ 6] Mohammadine El Haddad; Abdelmajid Regti; Rachid Slimani and Sald Lazar (2014). Assessment of the biosorption kinetic and thermodynamic for the removal of safranin dye from aqueous solutions using calcined mussel shells. J. Ind. Eng. Chem., 20: 717-724. doi: http://dx.doi.org/10.1016/j.jiec.2013.05.038

[ 7] Shariati, S.; Faraji, M.; Yamini, Y. and Rajabi, A.A. (2017). Fe3O4 magnetic nanoparticles modified with sodium dodecyl sulfate for removal of safranin $\mathrm{O}$ dye. Desalination, 270: 160-165. doi:10.1016/j.desal. 2010.11.040

[ 8] Fatima, H.; Abdullah, M.A.; Rauf, S. and Salman Ashraf (2007) Photolytic oxidation of Safranin-O with H2O2, Dyes Pigm., 72: 349-352. doi: https://doi.org/10.1016/j.dyepig.2005.09.015

[9] Salim Bekkouche; Slimane Merouani; Oualid Hamdaouib and Mohamed Bouhelassa (2017). Efficient photocatalytic degradation of Safranin $\mathrm{O}$ by integrating solar-UV/ $/ \mathrm{TiO}_{2} /$ persulfate treatment: Implication of sulfate radical in the oxidation process and effect of various water matrix components, $J$. Photochem. Photobiol. A, 345: 80-91.

[ 10] Crini, G. (2006). Non-conventional low-cost adsorbents for dye removal: A review, Bioresour. Technol., 97: 1061-1085. doi: https://doi.org/10.1016/j.biortech.2005.05.001
[11] Hsing, H.J.; Chiang, P.C.; Chang, E.E. and Chen, M.Y. (2007). The decolorization and mineralization of Acid Orange 6 azo dye in aqueous solution by advanced oxidation processes: acomparative study, J. Hazard. Mater., 141: 8-16. doi: https://doi.org/10.1016/ j.jhazmat.2006.05.122

[ 12] Roy, D.; Valsaraj, K.T. and Kottai, S.A. (1992). Separation of organic dyes from wastewater by using colloidal gas aphrons. Sep. Sci. Technol., 27: 573-588. doi: https://doi.org/10.1080/01496399208018903

[13] Pak, D. and Chang W. (2002). Color and suspended solid removal with a novel coagulation technology, Water Sci. Technol.: Water Supply, 2: 77-81.

[ 14] Aleboyeh, A.; Aleboyeh, H. and Moussa, Y. (2003). Critical effect of hydrogen peroxide in photochemical oxidative decolorization of dyes: Acid Orange 8, Acid Blue 74 and Methyl Orange, Dyes Pigm., 57: 67-75. doi: https://doi.org/10.1016/S0143-7208(03)00010-X

[ 15] Parshetti G.; Kalme S.; Saratale G. and Govindwar, S. (2006). Biodegradation of malachite green by Kocuria rosea MTCC 1532, Acta Chim. Slov., 53: 492-498.

[16] Jinisha, R.; Gandhimathi, R.; Ramesh, S.T.; Nidheesh, P.V. and Velmathi S. (2018). Removal of rhodamine B dye from aqueous solution by electroFenton process using iron-doped mesoporous silica as a heterogeneous catalyst. Chemosphere, 200: 446-454. doi: https://doi.org/10.1016/j.chemosphere.2018.02.117

[17] Erol Alver and Aysegul U. Metin (2012). Anionic dye removal from aqueous solutions using modified zeolite: Adsorption kinetics and isotherm studies. Chem. Eng. J., 200-202: 59-67. doi: http://dx.doi.org/10.1016/j.cej.2012.06.038

[ 18] Farnaz, Hemmatia; Reza, Norouzbeigi; Farimah, Sarbisheh and Hadi, Shayesteh (2016). Malachite green removal using modified sphagnum peat moss as a low-cost biosorbent: Kinetic, equilibrium and thermodynamic studies. J. Taiwan Inst. Chem. Eng., 58: 482-489. doi: http://dx.doi.org/10.1016/j.jtice.2015.07.004

[19] M. Hamdi Karaoğlu; Mehmet Doğanb and Mahir Alkan (2009). Removal of cationic dyes by kaolinite. Microporous Mesoporous Mater., 122: 20-27. doi: https://doi.org/10.1016/j.micromeso.2009.02.013

[20] Zhihui, Huang; Yuzhen, Li; Wenjun, Chen; Jianhui, Shi; Ning, Zhang; Xiaojin, Wang Zhen, Li; Lizhen, Gao and Yuxin, Zhang (2017). Modified bentonite adsorption of organic pollutants of dye wastewater. Mater. Chem. Phys., 202: 266-276. doi: https://doi.org/10.1016/j.matchemphys.2017.09.028

[21] Maria Leah Flor, A.; De Castro; Melody Love, B. Abad; Divine Angela, G. Sumalinog and Ralf Ruffel M. Abarca (2018). Peerasak Paoprasert; Mark Daniel G. de Luna. Adsorption of Methylene Blue dye and $\mathrm{Cu}(\mathrm{II})$ ions on EDTA-modified bentonite: Isotherm, kinetic and thermodynamic studies. Sustainable 
Environ. Res., xxx: 1-9. doi: https://doi.org/10.1016/ j.serj.2018.04.001

[22] Rizka Fabryantya; Chrissila Valencia; Felycia Edi Soetaredjo; Jindrayani Nyoo Putrob; Shella Permatasari Santoso; Alfin Kurniawanb and Yi-Hsu Jub and Suryadi Ismadjia. (2017). Removal of crystal violet dye by adsorption using bentonite - alginate composite. J. Environ. Chem. Eng., 5: 5677-5687. http://dx.doi.org/10.1016/j.jece.2017.10.057

[23] Al-Shahrani, S.S. (2013). Removal of malachite green from wastewater using Khulays natural bentonite. Official conference proceeding, the European Conference on Sustainability, Energy and the Environment.

[24] Sumanjit Kaur; Seema Rani; Mahajan, R.K.; Asif, M. and Vinod Kumar Gupta (2015). Synthesis and adsorption properties of mesoporous material for the removal of dye safranin: Kinetics, equilibrium, and thermodynamics. J. Ind. Eng. Chem., 22: 19-27. doi: http://dx.doi.org/10.1016/j.jiec.2014.06.019.

[ 25] Zhihui Huang; Yuzhen Li; Wenjun Chen; Jianhui Shi; Ning Zhang; Xiaojin Wang; Zhen Li; Lizhen Gao and Yuxin Zhang (2017). Modified bentonite adsorption of organic pollutants of dye wastewater. Mater. Chem. Phys. 202: 266-276. doi: https://doi.org/10.1016/j.matchemphys.2017.09.028.

[26] Eren, E. (2009). Removal of basic dye by modified Unye bentonite, Turkey. J. Hazard. Mater., 162:13551363. doi: https://doi.org/10.1016/j.jhazmat.2008.06.016

[27] Sílvia C.R. Santos; Alvaro F.M. Oliveira and Rui A.R. Boaventura (2016). Bentonitic clay as adsorbent for the decolourisation of dye house effluents. J. Cleaner Prod., 126: 667-676. doi: http://dx.doi.org/10.1016/ j.jclepro.2016.03.092.

[ 28] Langmuir, I. (1918). Langmuir, the adsorption of gases on plane surfaces of glass, mica and platinum. J. Am. Chem. Soc., 40: 1361-1403. doi: http://dx.doi.org/ 10.1021/ja02242a004.
[ 29] Freundlich, H. (1906). Over the Adsorption in Solution. J. Phys. Chem., 57: 385-471.

[ 30] Angelova, A. and Ionov, R. Ionov (1999). Monolayer and Spectroscopic Studies of an Amphiphilic (Phenylethynyl) anthracene Probe in Pure and Mixed Films with Charged and Neutral Lipids. Langmuir, 15: 7199-7207. doi: http://dx.doi.org/10.1021/la981536p.

[ 31] Hirahara, M. and Umemura, Y. (2015). Fabrication of Three-Layer-Component Organoclay Hybrid Films with Reverse Deposition Orders by a Modified LangmuirSchaefer Technique and Their Pyroelectric Currents Measured by a Noncontact Method. Langmuir, 31: 8346-8353. doi:http://dx.doi.org/10.1021/acs.langmuir.5b01401

[ 32] Ulman, A. (1991). An Introduction to Ultrathin Organic Films: From Langmuir- Blodgett Films to Selfassembly, 1st ed.; Academic press, NewYork.

[33] Fayazi, M.; Afzali, D.; Taher, M.A.; Mostafavi, A. and Gupta, V.K. (2015). Removal of Safranin dye from aqueous solution using magnetic mesoporous clay: Optimization study. J. Mol. Liq., 212: 675-685. doi: http://dx.doi.org/10.1016/j.molliq.2015.09.045.

[34] Mohamed Mana; Mohand-Said Ouali and de Menorval, L.C. (2007). Removal of basic dyes from aqueous solutions with a treated spent bleaching earth. $J$. Colloid Interface Sci., 307: 9-16. doi: https://doi.org/10.1016/j.jcis.2006.11.019

[ 35] Ozcan, A.S.; Erdem, B. and Ozcan, A. (2005). Adsorption of Acid Blue 193 from aqueous solutions onto BTMA bentonite. Colloids Sur. A, 266: 73-81. doi: https://doi.org/10.1016/j.colsurfa.2005.06.001

[ 36] Ho, Y. S. and Mckay, G. (1998). Kinetic models for the sorption of dye from aqueous solution by wood. Proc. Saf. Environ. Prot., 76: 183-191.

[ 37] Ho, Y. S.; Ng, J. C. Y. and Mckay, G. (2000). Kinetics of pollutant sorption by biosorbents: Review. Sep. Purif. Methods, 29: 189-232. doi: https://doi.org/10.1081/ SPM-100100009. 
إزالة صبغة السفرانين من مياه الصرف باستخدام بنتونايت خليص الطبيعي

\section{سعد سعيد الثهراني}

قسم الهندسة الكيميائية وهندسة المواد، جامعة الملك عبدالعزبز، جدة 019 1 ، المعلكة العربية السعودية ssaalshahrani@kau.edu.sa

المستخلص. تمت في هذا البحث دراسة استخدام خام بنتونيت خليص الطبيعي كمادة منخفضة التكلفة لإزالة صبغة السفرانين من مياه الصرف، حيث تمت دراسة عملية الإزالة باستخدام تجارب الامتزاز باسلوب الدفعات. كما تمت دراسة تأثير العوامل المختلفة على عملية الامتزاز بما في ذلك زمن المزج وتركيز الصبغة المبدئي ودرجة الحامضة المبدأية للمحلول، وجرعات خام بنتونايت خليص الطبيعي. تم تطبيق نماذج الآيسوثيرم على عملية الامتزاز بهدف تقدير خصائص الاتزن لعملية الامتزاز، وتقييم مدى قابلية تطبيقها، واقتراح التصميم المناسب لها. تمت دراسة حركية الامتزاز باستخدام نموذج الدرجة الأولى ونموذج الدرجة الثانية وتطبيقهما

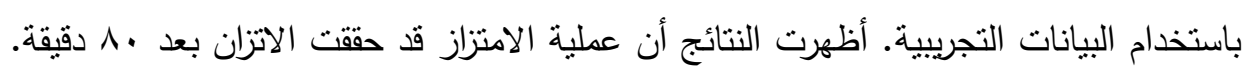
وقد أثتتت النتائج أن عملية إزالة صبغة السفرانين تعتمد على درجة حامضية المحلول المبدئية،

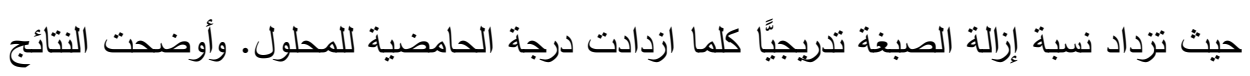
أنه مع زيادة تركيز صبغة السفرانين انخفضت نسبة الإزالة بسبب محدودية المواقع النشطة على تلى النى أسطح البنتونيت، وبالتالي النتبع بصبغة السفرانين. كما أوضحت البيانيز البيات التجريبية أن ايسوثيرم الامنزاز باستخدام معادلات لانجميور وفروندلينش تميل إلى نموذج لانجيمور أكثر من نموذج

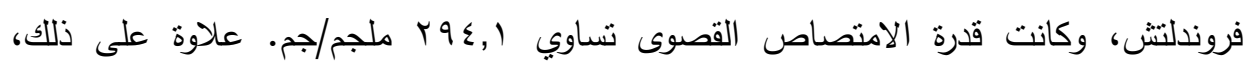
أظهرت النتائج التجريبية أن حركية امتزاز صبغة السفرانين باستخدام خام بنتونيت خليص الطبيعي تتبع نموذج الدرجة الثانية.

كلمات مفتاحبة: بنتونايت خليص الطبيعي، امتزاز صبغة السفرانين، امتزاز صبغة السفرانين،

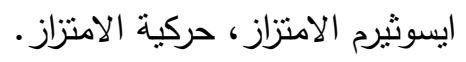

